\title{
Application of multi-stage biofilter pilot plants to remove odor and VOCs from industrial activities air emissions
}

\author{
V. Torretta ${ }^{1}$, M. Raboni ${ }^{1}$, S. Copelli ${ }^{1} \&$ P. Caruson ${ }^{2}$ \\ ${ }^{I}$ Department of Science and High Technology, \\ University of Insubria, Varese, Italy \\ ${ }^{2}$ AirClean Srl, Rho, Italy
}

\begin{abstract}
This study includes trials that were conducted to evaluate the performances of two biofiltration pilot plants for industrial applications. The first experimentation analyzed the removal of high concentrations of Volatile Organic Compounds (VOCs) from discontinuous gas emissions resulting from the flexographic printing section of a plastic packaging production factory. The adopted layout for the experimentation was a multi-stage plant filled with two different packing materials (shells and peat). The second trial examined the biofiltration of exhaust air from a Solid Recovered Fuel (SRF) drying process treating the dry fraction of municipal solid waste (MSW). Such exhaust streams are characterized by low VOCs content but high odorous compounds, such as $\mathrm{H}_{2} \mathrm{~S}$ and $\mathrm{NH}_{3}$. The pilot plant used for the experimentation had two stages that used shells as packing material. In both cases, the multi-stage biofilter performances indicate that the solutions are suitable as well as applicable for use in industrial plants.

Keywords: air pollution, biofiltration, biotrickling filter, odor, packing material, plastic, SRF, VOC.
\end{abstract}

\section{Introduction}

Biofiltration is an emerging and attractive technology for the removal of Volatile Organic Compounds (VOCs) present at low concentrations [1-4]. Traditional VOCs removal technologies involve physical or chemical processes, such as adsorption, condensation, thermal incineration or catalytic conversion [5]. Compared with these technologies, biofiltration has low life cycle costs and it is 
robust as well as reliable $[6,7]$. The importance of the biofiltering performances optimization has been pointed out recently, taking into account that these devices usually release the treated gas at very low concentration levels [8-10], with a consequent reduced ability of dilution into the atmosphere. This aspect sometimes causes local problems of smell and concerns in the nearby population [9-12]. It is clear that the sector must foster the improvement of performances of these devices. The adoption of pilot experiences before the design of a real scale plant is in agreement with such a vision.

This paper presents the results of two case-studies on biofiltration pilot plants treating the exhausted gases of:

- the flexographic printing section of a plastic packaging industry;

- a plant for the production of solid recovered fuel (SRF) from municipal solid waste (MSW).

In the first case the total flow of emissions into the atmosphere are 35,000 $\mathrm{Nm}^{3} \mathrm{~h}^{-1}$ at approximately $40^{\circ} \mathrm{C}$. The VOCs content is in the range $900 \div 3,800 \mathrm{mg} \mathrm{m}^{-3}$ with the following composition (estimated through the plant solvent consumption): ethyl alcohol (53\%), ethyl acetate (36\%), isopropanol (5\%), methyl ethyl ketone (MEK) and methoxypropanol (3\%, respectively).

The plant works discontinuously $12 \mathrm{~h}$ every day and 5 days per week, with the expectation that the working time could increase to $18 \mathrm{~h}$ per day.

The second case study concerns a plant that treats the dry separated waste originated from Italian MSW. The effective energy recovery of the SRF is achieved by directly co-burning in concordance with the new regulation [13, 14]. The final destination of the residuals is the landfill. The SRF production entails a sequence of operations: selection, shredding, drying and mixing of fuel with other components with a high calorific value, such as chlorine-free plastics resulting from selective collection, rubber scraps and end-of-life tires. The SRF production is performed entirely in a depressurized production facility equipped with an air treatment system containing:

- one venturi scrubber for dust abatement pretreatment [15];

- three chemical scrubbers for treating VOC emissions [15].

The typical off-gas inlet emissions are composed of VOCs $\left(100 \mathrm{mg} \mathrm{Nm}^{-3}\right)$, $\mathrm{H}_{2} \mathrm{~S}\left(10 \mathrm{mg} \mathrm{Nm}^{-3}\right), \mathrm{NH}_{3}\left(10 \mathrm{mg} \mathrm{Nm}^{-3}\right), \mathrm{CO}\left(10 \mathrm{mg} \mathrm{Nm}^{-3}\right)$, NOx $\left(10 \mathrm{mg} \mathrm{Nm}^{-3}\right)$ and dust $\left(10 \mathrm{mg} \mathrm{Nm}^{-3}\right)$.

The abatement efficiencies achieved with these technologies $(50 \%$ of the inlet contaminants [9]) does not meet the standards imposed by the Italian local authority and the Environmental Agency (VOCs: $15 \mathrm{mg} \mathrm{Nm}^{-3}$; odor limit: 300 $\mathrm{OU} \mathrm{Nm^{-3 }}$ ).

This paper presents an approach for improving and solving these issues using multi-stage biofiltration systems composed of biotrickling filters (BTFs) and biofilters (BFs) [5] with two types of packing materials. 


\section{Materials and methods}

\subsection{Pilot plants description}

The biofiltration pilot plant layout adopted in Case 1 (flexographic printing section) is composed of three sections (Figure 1):

- a single-stage $\left(5.5 \mathrm{~m}^{3}\right.$ volume $)$ and a two-stage $\left(3.5+4.0 \mathrm{~m}^{3}\right.$ volume $)$ biotrickling filters (BTF1 and BTF2) filled with bioactive shells of Mytilus edulis (Monashell ${ }^{\circledR}$ patent; Figure 2(a));

- a finishing single-stage $\left(6.0 \mathrm{~m}^{3}\right.$ volume $)$ biofilter $(\mathrm{BF} 3)$ that uses peat as support media (Monafill ${ }^{\circledR}$ patent; Figure 2(b)).

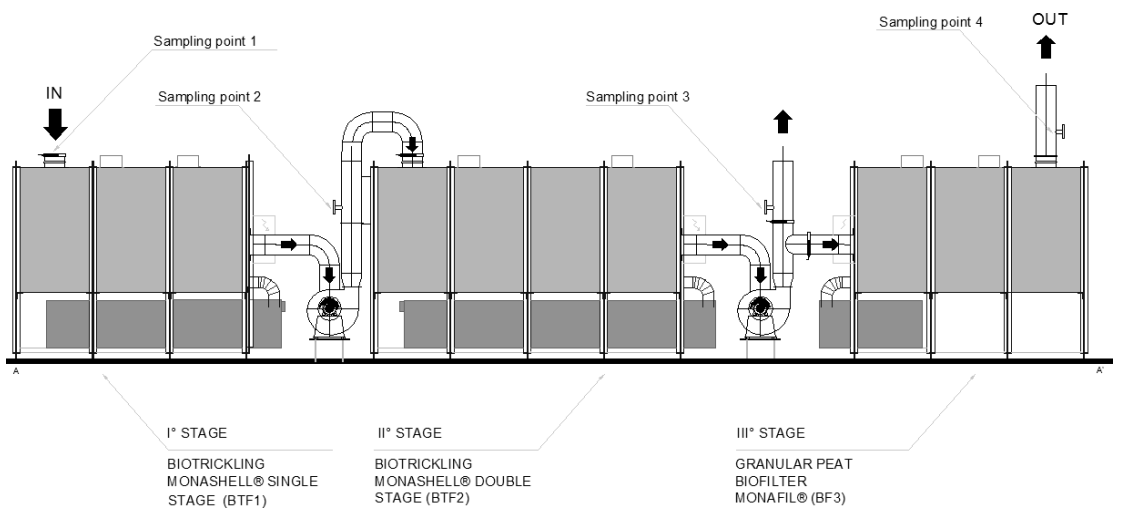

Figure 1: Biofiltration pilot plant 1 layout.
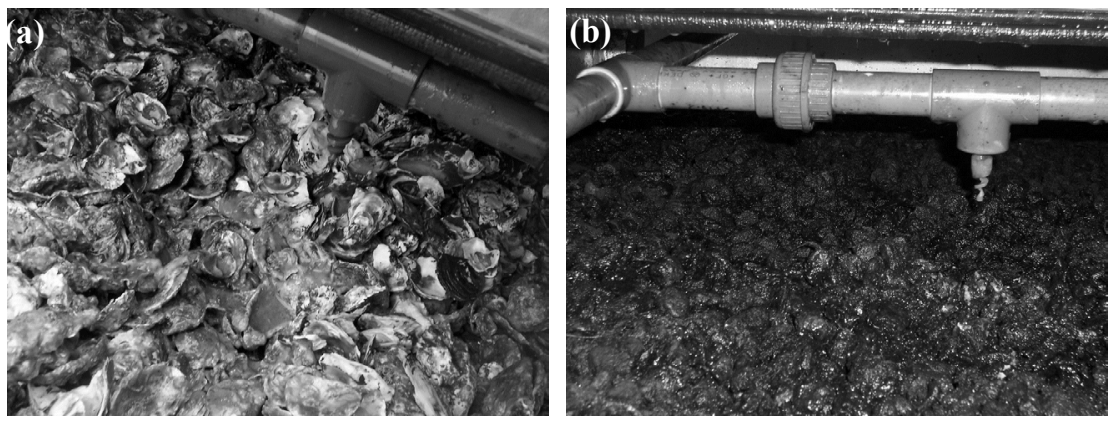

Figure 2: $\quad$ Pictures of (a) the biotrickling filters (shells of Mitilus edulis) and (b) the biofilter (peat) packing material.

Mytilus edulis shells, being rich of calcium carbonate $\left(\mathrm{CaCO}_{3}\right)$, exhibit a high buffering power and a strong affinity for slightly acidic compounds that, even if not present into the off air to be treated, are unavoidably produced during microbial metabolic activities. 
The processing unit can treat a flow of 1000-2000 $\mathrm{m}^{3} \mathrm{~h}^{-1}$ controlled by a manual valve. The plant also includes:

- two tanks for recirculating, respectively, BTF1 and BTF2 trickling liquid

- thermostat-equipped electric heaters controlling trickling liquid temperature. The temperature, which is an essential parameter for the proper functioning of the plant, was set to an ideal value for mesophilic bacteria growth $\left(25^{\circ} \mathrm{C}\right)$.

The normal operation of the pilot plant produces approximately $0.5 \mathrm{~m}^{3} \mathrm{~d}^{-1}$ of wastewater containing, essentially, salts and other by-products of bacterial oxidation. Biotrickling filters wastewaters and biofilter exhaust water are collected into a tank before the treatment in a wastewater treatment plant.

In the second case study (SRF from MSW production), the biofiltering system is connected to a temporary ductwork system taking air downstream the venturi scrubber. The plant is composed of two biotrickling filters filled with Mitilus edulis shells (Monashell ${ }^{\circledR}$ patent), treated with a specific process before installation. The pilot plant layout is shown in Figure 3.

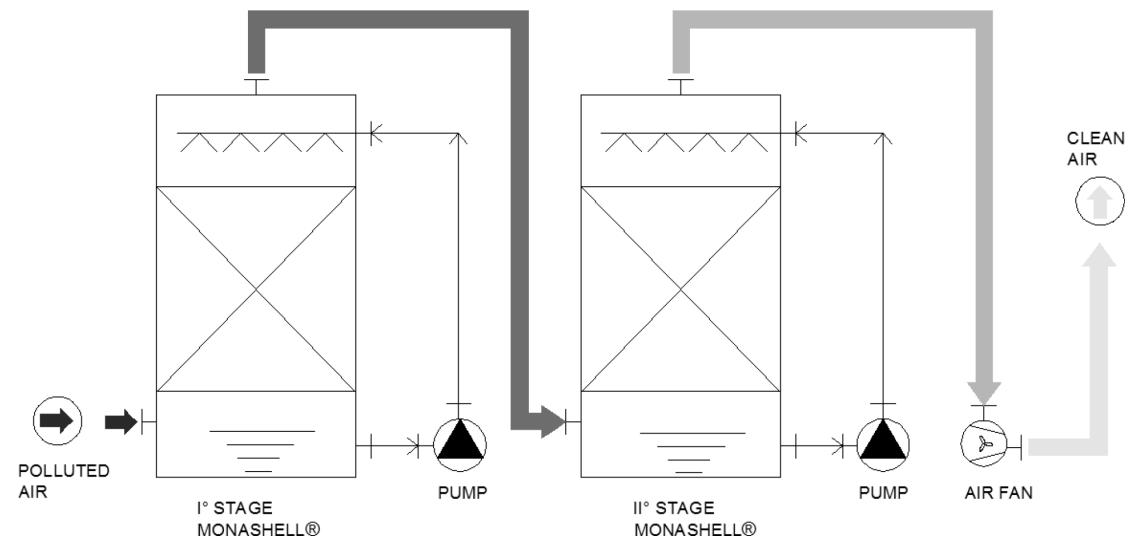

Figure 3: Biofiltration pilot plant 2 layout.

For the test, the airflow was set to $1000 \mathrm{~m}^{3} \mathrm{~h}^{-1}$. Each stage of the pilot plant has the following features:

- Volume: $3.3 \mathrm{~m}^{3}$;

- Packing material height: $0.9 \mathrm{~m}$;

- Trickling liquid flowrate: $0.010 \mathrm{~m}^{3} \mathrm{~min}^{-1}$

The overall Empty Bed Residence Time (EBRT) is $12 \mathrm{~s}$.

The pictures of the pilot plants are shown in Figure 4.

No nutrients and oligoelements have been added to the trickling liquid (aqueduct water). A selected consortium of microbial population was decided to be inoculated in order to lower start-up times and, meanwhile, improve biotrickling filters efficiency in terms of total abatable mass. 


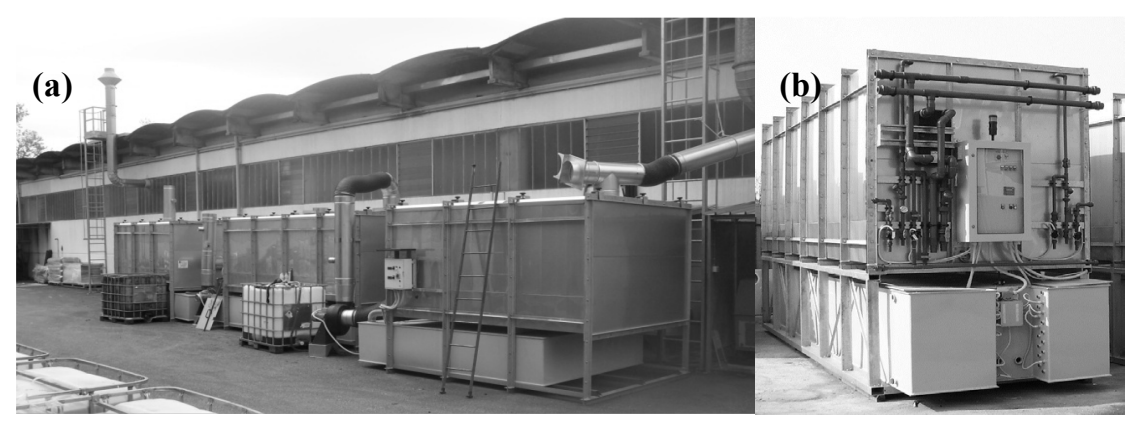

Figure 4: $\quad$ Pictures of the pilot plant 1 (a) and 2 (b).

\subsection{Experiments and analysis description}

The pilot plant 1 ran for a period of 12 weeks, during which chemical analysis on air samples and chemical and microbiological analysis on the washing recirculating water were conducted. Air sampling points are shown in Figure 1.

The test program involved the following steps:

- weeks 1 and 2: bacteria inoculation and acclimatization, low-flow running, trickling liquid temperature of $30^{\circ} \mathrm{C}$;

- $\quad$ weekend 2: chemical tests on every single-unit (Test 1);

- weeks 3 and 4: maximum flow rate;

- $\quad$ weekend 4: chemical tests on every single-unit stage (Test 2);

- weeks 5 and 6: maximum flow rate with 50\% false air

- weekend 6: chemical tests on every single-unit stage (Test 3);

- $\quad$ weeks 7 and 8: reduced flow rate with 50\% false air

- weekend 8: chemical tests on every single-unit stage (Test 4);

- weeks 9, 10, 11, and 12: running with all parameters optimized after previous test results;

- weekend 10 and weekend 12: chemical tests (Test 5).

Test 1, 2, 3 and 4 gas samples were analyzed using ethyl acetate (the most recalcitrant VOC present in exhausted air) test tubes. Test 5 gas samples were subjected to a detailed analysis of VOCs. Air samples were collected onto suitable sorbent tubes using SKC sample pumps. Following desorption, the samples were analyzed by Gas Chromatography Mass Spectrometry (GC-MS). This system consists of a Varian Gas Chromatograph equipped with a high resolution capillary column interfaced with a Finnigan Matt ITS40 Mass [12]. : Results are listed in Tables 1 and 2.

The pilot plant 2 ran for a period of eight weeks. VOCs concentration and odor measurements were monitored, respectively, at the biofiltration plant inlet and the outlet. Olfactometric tests were carried out using forced choice dynamic olfactometry technique. Every weekend, a microbiological analysis of the exhausted water was carried out.

Total VOCs concentration results are shown in Figure 5 and olfactometric results are listed in Table 3. 


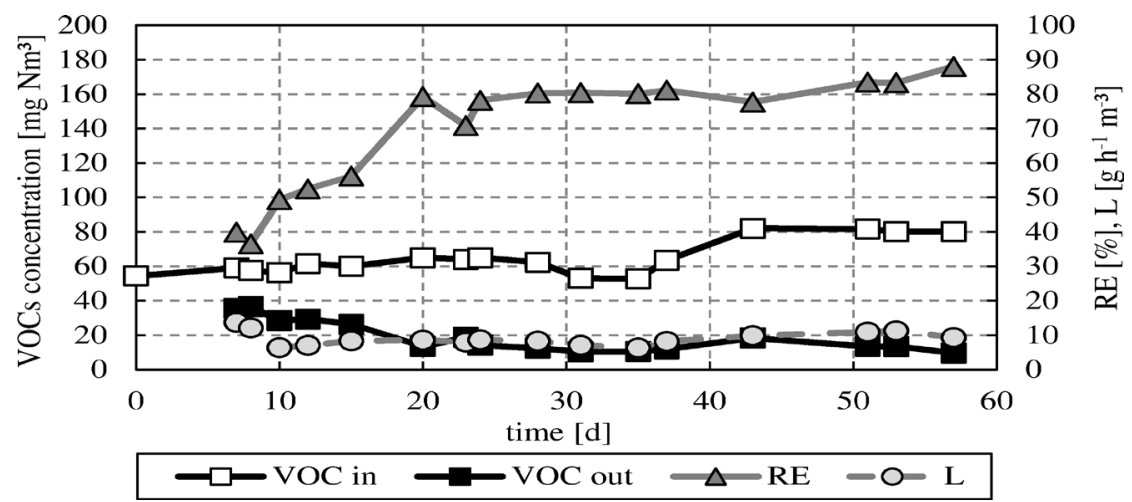

Figure 5: Case 2 experiments with VOC concentrations, removal efficiencies $(R E)$ and loading rates $(L)$.

Pollutant loading ( $L_{s}$, in $\mathrm{g} \mathrm{h}^{-1} \mathrm{~m}^{-3}$ of packing material) and removal efficiencies ( $R E_{s}$, as percentage) of each stage $s$ has been calculated.

\section{Results and discussion}

Concerning the first experimentation, the results for ethyl acetate are shown in Table 1 as temperature $\left(T_{i n}\right)$ and input concentrations to the air treatment system $\left(C_{i n}\right)$, concentrations at the exit stack $\left(C_{\text {out }}\right.$ as well as the inlet loading rate. The single section and overall removal efficiencies of the treatment are shown.

Table 1: $\quad$ Plant 1 chemical analysis results on ethyl acetate.

\begin{tabular}{|c|c|c|c|c|c|}
\hline PARAMETER & M.U. & TEST 1 & TEST 2 & TEST 3 & TEST 4 \\
\hline BTF 1 AIR TEMPERATURE $\left(T_{I N}\right)$ & ${ }^{\circ} \mathrm{C}$ & 23.7 & 24.5 & 27 & 25.3 \\
\hline OFF-GAS INLET CONCENTRATION $\left(C_{I N}\right)$ & $\mathrm{MG} \mathrm{NM}^{-3}$ & 590 & 3931 & 1572 & 3931 \\
\hline LOADING RATE $(L)$ & $\mathrm{G} \mathrm{H}^{-1} \mathrm{M}^{-3}$ & 407 & 3138 & 1216 & 2878 \\
\hline SINGLE-STAGE BTF $1 R E\left(R E_{1}\right)$ & $\%$ & 80.0 & 50.0 & 45.0 & 77.0 \\
\hline DUAL-STAGE BTF $2 R E\left(R E_{2}\right)$ & $\%$ & 50.0 & 70.0 & 54.5 & 84.8 \\
\hline SINGLE-STAGE BF3 $R E\left(R E_{3}\right)$ & $\%$ & 33.3 & 73.3 & 40.0 & 71.4 \\
\hline OFF-GAS OUTLET TEMPERATURE $\left(T_{\text {OUT }}\right)$ & ${ }^{\circ} \mathrm{C}$ & 7.3 & 14.0 & 13.0 & 8.0 \\
\hline $\begin{array}{l}\text { OFF-GAS OUTLET CONCENTRATION } \\
\left(C_{\text {OUT }}\right)\end{array}$ & $\mathrm{MG} \mathrm{NM}^{-3}$ & 39 & 157 & 236 & 39 \\
\hline PLANT OVERALL $R E\left(R E_{T o T}\right)$ & $\%$ & 93.3 & 96.0 & 85.0 & 99.0 \\
\hline
\end{tabular}

Results demonstrate the importance of a multi-step approach in order to reach the performances required from the current European environmental regulation. The obtained global efficiency is high: three tests out of four got an efficiency higher than $94 \%$.

The results reported in Table 1 concerns a molecule with low degradability and represent the worst operating condition. If we consider the results and the 
removal yields for other compounds (Table 2) at the final working conditions, it is possible to determine the effectiveness of the adopted technical solution. Considering molecules with good biodegradability (e.g. methoxypropanol), a removal yield of $99.6 \%$ resulted. Less biodegradable molecules (e.g. MEK and ethyl acetate) also resulted in high removal yields: from $97.8 \%$ for isopropanol to $76.7 \%$ for ethyl acetate (only removed by the third stage, the biofilter). An increase of the other VOCs compounds (with low concentrations) can be due to by-products of biological degradation.

Table 2: $\quad$ Plant 1 sampling campaign results with all of the compounds.

\begin{tabular}{|l|r|r|r|r|r|r|}
\hline Compound & $\begin{array}{c}\boldsymbol{C}_{\text {in }} \\
{\left[\mathbf{m g ~ N m}^{-3}\right]}\end{array}$ & $\begin{array}{c}\boldsymbol{L}_{\boldsymbol{I}} \\
{\left[\mathbf{g ~ h}^{\mathbf{- 1}} \mathbf{~ m}^{-\mathbf{3}}\right]}\end{array}$ & $\begin{array}{c}\boldsymbol{R} \boldsymbol{E}_{\boldsymbol{1 + 2}} \\
{[\mathbf{\%}]}\end{array}$ & $\begin{array}{c}\boldsymbol{R} \boldsymbol{E}_{\mathbf{3}} \\
{[\mathbf{\%}]}\end{array}$ & $\begin{array}{c}\boldsymbol{C}_{\text {out }} \\
{\left[\mathbf{m g ~ N m}^{-3}\right]}\end{array}$ & $\begin{array}{c}\boldsymbol{R} \boldsymbol{E}_{\text {tot }} \\
{[\mathbf{\%}]}\end{array}$ \\
\hline Methoxypropanol & 127.8 & 249 & 86.7 & 97.3 & 0.46 & 99.6 \\
\hline MEK & 121.1 & 236 & 54.6 & 89.6 & 5.72 & 95.3 \\
\hline Isopropanol & 198.8 & 388 & 94.4 & 90.6 & 1.05 & 99.5 \\
\hline Ethyl acetate & 1499.7 & 2924 & 3.5 & 76.0 & 346.84 & 76.9 \\
\hline Ethyl alcohol & 2226.4 & 4341 & 52.5 & 90.6 & 99.61 & 95.5 \\
\hline Other VOCs & 3.2 & 6 & -2368 & 86.3 & 10.70 & -239 \\
\hline Total VOCs & 4176.9 & 8145 & 36.2 & 82.6 & 464.39 & 88.9 \\
\hline
\end{tabular}

The system proved to be very effective in removing high concentration of solvents (particularly for more soluble compounds). This result was possible because biotrickling technologies were used instead of conventional biofiltration. Biofilters can be used only for low concentration airstreams [4], as it was also proven in this study, were a biofilter was adopted as final polishing stage. Moreover, seashells offer significant advantage for VOCs removal in terms of $\mathrm{pH}$ control as well as nutrients and micronutrients released by the media.

In the second case-study, the enhanced pilot was able to reduce the odor concentrations at the outlet stack to less than $300 \mathrm{OU} \mathrm{m}^{-3}$ and the VOCs emissions to less than $15 \mathrm{mg} \mathrm{Nm}^{-3}$, as shown in Figure 4 and Table 3.

Table 3: $\quad$ Odor concentrations and removal efficiencies of pilot plant 2 .

\begin{tabular}{|c|c|c|c|}
\hline Day & $\begin{array}{c}\text { Odor concentration - Inlet [OU } \\
\mathbf{N m}^{-3} \text { ] }\end{array}$ & $\begin{array}{c}\text { Odor concentration - Outlet } \\
\text { biofilter } \\
{\left[\mathbf{O . U} \text {. Nm } \mathbf{~ N}^{-3}\right.}\end{array}$ & RE \\
\hline 29 & 4,500 & 190 & 95.8 \\
\hline 37 & 4,880 & 220 & 95.4 \\
\hline 51 & 3,400 & 180 & 94.7 \\
\hline
\end{tabular}

After a period of two weeks, which was necessary for bacteria acclimation, the performance of the biofiltration system in terms of average percentage of abatement can be evaluated by the following efficiency parameters:

- odor removal efficiency: $95.4 \%$

- VOC removal efficiency: $81.0 \%$.

The total energy loss is around $60 \mathrm{mmH}_{2} \mathrm{O}$ per stage. 


\section{Conclusions}

In conclusion it is possible to say that in both cases, after the use of the proposed combination of biofiltration systems (biotrickling filters and biofilters) with different packing materials, the results showed very good performances. The odor and VOCs compounds removal yields met legal standards in the effluent air. This conclusion is in accordance with the technical literature and shows that biofiltration is a natural, energy saving and cost-effective technology, as suggested by European regulations regarding best available technologies and Integrated Pollution, Prevention and Control (IPPC). The results obtained from this study indicate that the pilot plants can be used at their full capacity for applications similar with the ones described in this work (discontinuous loading rates or high VOCs concentrations with odorous compounds). Chemical characteristics of seashells offer significant advantage for VOC removal in terms of $\mathrm{pH}$ control, and allow no continuous addition of nutrients rand micro nutrients.

Moreover, the importance of pilot experimentations is more relevant in the sector of bio-filtration, because of the potential impact of the emissions on the territory from releases into the atmosphere at low levels.

\section{Acknowledgements}

The author wishes to acknowledge AirClean Srl (Rho, Milan, Italy) and John Paul Phillips (Bord Na Mòna, Ireland) for their technical support and for making the pilot plants available for this study.

\section{References}

[1] Detchanamurthy, S., Gostomski, P.A. Biofiltration for treating VOCs: An overview. Reviews in Environmental Science and Biotechnology, 11(3), pp. 231-241, 2012.

[2] Kennes, C., Veiga, M.C. Technologies for the abatement of odours and volatile organic and inorganic compounds. Chemical Engineering Transactions, 23, pp. 1-6, 2010.

[3] Liu, Q., Li, M., Chen, R., Li, Z., Qian, G., An, T., Fu, J., Sheng, G. Biofiltration treatment of odors from municipal solid waste treatment plants. Waste Management, 29(7), pp. 2051-2058, 2009.

[4] Mahar, R.B., Yue, D., Liu, J., Zhang, Y., Nie, Y. Biological pretreatment of municipal solid waste prior to landfilling. Global Nest Journal, 11(4), pp. 510-517, 2009.

[5] Shareefdeen Z., Singh A., 2004, Biotechnology for odor and air pollution control, Heidelberg: Springer, New York, USA.

[6] Wang, Z., Govind, R. Review of Biofiltration - Effect of Support Media on Biofilter Performance. NRMRL, U.S. Environmental Protection Agency, Cincinnati, Dolloff F. Bishop, 2006. 
[7] Estrada, J.M., Kraakman, N.J.R., Lebrero, R., Muñoz, R. A sensitivity analysis of process design parameters, commodity prices and robustness on the economics of odour abatement technologies, Biotechnology Advances, 30(6), pp. 1354-1363, 2012.

[8] Ragazzi, M., Rada, E.C., Antolini, D., Material and energy recovery in integrated waste management systems: An innovative approach for the characterization of the gaseous emissions from residual MSW bio-drying, Waste Management, 31(9-10), pp. 2085-2091, 2011.

[9] Rada, E.C. Local environmental impact from MSW aerobic biological treatment. WIT Transactions on Ecology and the Environment, 163, pp. 1324, 2012.

[10] Rada, E.C., Ragazzi, M., Badea, A. MSW Bio-drying: Design criteria from A 10 years research, UPB Scientific Bulletin, Series D: Mechanical Engineering, 74(3), pp. 209-216, 2012.

[11] Govind, R. Review of biofiltration and its implications for climate change. Proc. of the the Air and Waste Management Association's Annual Conference and Exhibition, AWMA 6, pp. 4155-4167, 2009.

[12] Copelli, S., Torretta, V., Raboni, M., Viotti, P., Luciano, A., Mancini, G., Nano, G. Improving biotreatment efficiency of hot waste air streams: experimental upgrade of a full plant, Chemical Engineering Transactions, 30, pp. 49-54, 2012.

[13] Ragazzi, M. and Rada, E.C. RDF/SRF evolution and MSW bio-drying, WIT Transactions on Ecology and the Environment, 163, 199-208, 2012.

[14] Rada, E.C., Andreottola, G. RDF/SRF: Which perspective for its future in the EU. Waste Management, 32(6), pp. 1059-1060, 2012.

[15] Perry R.H., Green D.W., 1999, Perry's Chemical Engineers' Handbook, McGraw Hill, New York, USA. 